\title{
Evaluation of Quaternized and Neutral Muscarinic Receptor Ligands in Normal and DES-treated Rat
}

\author{
C. A. OTTO', G. K. MULHOLLAND'², S. B. DEMATTOS', \\ P. S. SHERMAN ${ }^{2}$, T. L. PISANI ${ }^{2}$ and G. HINGORANI ${ }^{1}$ \\ 'The University of Michigan-Dearborn, Dearborn, MI 48128 and ${ }^{2}$ The Division of Nuclear Medicine, \\ University of Michigan Medical Center, Ann Arbor, MI 48109, U.S.A.
}

(Received 29 March 1990; for publication 21 September 1990)

\begin{abstract}
The localization of quaternized muscarinic receptor $(\mathrm{mAChR})$ antagonists, $\left[{ }^{\prime \prime} \mathrm{C}\right]$ methyl tropanyl benzilate ([" $\left.{ }^{11} \mathrm{C}\right] \mathrm{MTRB}$ ) and [" $\left.{ }^{1} \mathrm{C}\right] \mathrm{methyl}$ quinuclidinyl benzilate ([" $\left.\left.\mathrm{C}\right] \mathrm{MQNB}\right)$, in rat pituitary was compared to that of ["C]tropanyl benzilate (["C]TRB), a neutral antagonist. The quaternized ligands localize via a $\mathrm{mAChR}$-mediated mechanism as shown by $60 \%$ reduction in radioactivity concentrations in the presence of QNB. ["C]TRB appears to localize primarily by a non-mAChR specific mechanism. Induction of pituitary prolactinomas by diethylstilbestrol resulted in a reduction of $\left.{ }^{11} \mathrm{C}\right] \mathrm{MTRB}$ pituitary localization compared to normals. Elevated serum prolactir levels due to prolactinoma presence had no measurable effect on myocardial ["C]MTRB uptake or on $K_{\mathrm{D}}$ values. $B_{\max }$ values for myocardial mAChR were similar for controls and for DES exposure of 10 weeks.
\end{abstract}

Muscarinic receptors (mAChRs) are intrinsic membrane proteins found in many tissues which elicit an array of biochemical responses from control of heart rate to neurotransmission in the brain. Imaging these receptors could yield medically useful data from both the central nervous system and peripheral organs such as the heart. Rather than synthesizing a large number of potential ligands in radioactive form, we developed a two stage assay system to preselect target ligands. The first stage consisted of a competitive in vitro binding assay designed to provide information on relative binding affinities. The second stage was an ex vivo assay which provided information on both in vivo distribution and kinetics (Otto et al., 1989). Application of this screening procedure lead to radiosynthesis and further studies of the following ligands: $\left[{ }^{11} \mathrm{C}\right]-(+)-2 \alpha$-tropanyl benzilate $\left(\left[{ }^{11} \mathrm{C}\right] \mathrm{TRB}\right)$ and $\left[{ }^{11} \mathrm{C}\right]-$ $N$-methyl piperidyl benzilate ([ $\left.{ }^{11} \mathrm{C}\right] \mathrm{NMPB}$ ) (Mulholland et al., 1988a,b, 1989) (see Fig. 1). Our initial objective in synthesizing ["C]MTRB was to check its feasibility as a myocardial imaging agent. Gibson et al. (1979) demonstrated that quaternization of $\left[{ }^{3} \mathrm{H}\right] \mathrm{QNB}$ to form $\left[{ }^{3} \mathrm{H}\right] \mathrm{MQNB}$ lead to better heart/lung ratios than observed with $\left[{ }^{3} \mathrm{H}\right] \mathrm{QNB}$. Other investigators, using $\left[{ }^{11} \mathrm{C}\right] \mathrm{MQNB}$, verified that the complications of non-specific lung uptake of neutral $\mathrm{mAChR}$ ligands were reduced with quaternization (Maziere et al., 1981; Syrota et al., 1985).
In studying $\left[{ }^{11} \mathrm{C}\right] \mathrm{MTRB}$ in vivo, we noted a difference in behavior between [ $\left.{ }^{\prime \prime} \mathrm{C}\right]$ TRB and [ ${ }^{\prime \prime}$ C]MTRB in the pituitary. Pituitary localization of both ligands was expected as $\mathrm{mAChRs}$ have been described in the pituitary (Avissar et al., 1981; Shaeffer and Hsueh, 1980; Burt and Taylor, 1980; Mukherjee et al., 1980). The in vivo demonstration of $\mathrm{mAChR}$-mediated pituitary localization of $\left[{ }^{3} \mathrm{H}\right] \mathrm{NMPB}$ (Avissar et al., 1981) together with the difference in behavior of the tropanyl benzilate ligands prompted a more thorough evaluation of "C labeled muscarinic antagonists in the pituitary.

Having an interest in detecting the presence of pituitary prolactin secreting adenomas (prolactinomas), we evaluated both [ $\left.{ }^{11} \mathrm{C}\right] \mathrm{TRB}$ and $\left[{ }^{11} \mathrm{C}\right] \mathrm{MTRB}$ in a rat model for prolactinoma. Diethylstilbestrol (DES) implanted in the F344 rat lead to increased serum prolactin levels (Wiklund $e$ t al., 1981). Further characterization of this model verified the increases in serum prolactin levels and pituitary weight, and documented increases in percent prolactin secreting cells (Otto et al., 1986a). Although the role of the $\mathrm{mAChR}$ receptor in the pituitary has yet to be sharply defined, there is evidence for cholinergic control of prolactin secretion (Carmeliet and Denef, 1988; Hall et al., 1984; Sharif, 1988). Comparison of $\mathrm{mAChR}$ antagonist localization in normal rat pituitary with localization in a prolactinoma model might 
reveal differences in mAChR density that would aid in understanding the role of cholinergic influence in the pituitary.

Our efforts were directed towards (1) comparing uptake of both neutral and quaternized $\mathrm{mAChR}$ radioligands in pituitary tissue, heart and brain, (2) evaluating the effects of DES-treatment on radiolabeled $\mathrm{mAChR}$ ligand uptake in pituitary, heart and brain and (3) determining the effects of high circulating prolactin levels on the biochemical characteristics $\left(B_{\max }\right.$ and $K_{\mathrm{D}}$ ) of myocardial $\mathrm{mAChR}$.

\section{Materials and Methods}

\section{Drugs}

Non-radioactive precursor $(+)-2 \alpha$-tropanyl benzilate (TRB) was prepared by base catalyzed transesterification of $(+)-2 \alpha$-tropanol with methyl benzilate (Atkinsonet al., 1977). $N$-Desmethyl-(+)-2 $\alpha$-tropanyl benzilate (nor-TRB) and (+)-2 $\alpha$-tropanol were kindly provided by $\mathrm{Dr}$ Edward R. Atkinson. $N$-Methyl4-piperidyl benzilate and 4-piperidyl benzilate were synthesized by literature procedures (Biel et al., 1961). (-)-Quinuclidinyl benzilate was purchased from Research Biochemicals Inc., Natick, Mass., U.S.A. Carbon-11 syntheses of $\left[{ }^{11} \mathrm{C}\right] \mathrm{TRB}, \quad\left[{ }^{11} \mathrm{C}\right] \mathrm{MTRB}$ (Mulholland et al., 1989), [ $\left.{ }^{11} \mathrm{C}\right] \mathrm{NMPB}$ (Mulholland et al., 1988a,b) and [ $\left.{ }^{11} \mathrm{C}\right] \mathrm{MQNB}$ (Syrota et al., 1985) were conducted by reacting the appropriate precursor (1-2 mg in $200 \mu \mathrm{L}$ of $N, N$-dimethyl formamide) with high specific activity [" $\mathrm{C}$ ]methyl iodide and then isolating products by normal phase chromatography. The radiochemical purities and specific activities of final formulated products were determined by analytical reversed phase HPLC $(4.6 \times 250 \mathrm{~mm}$ C- $185 \mu$, 3:1:1 acetonitrile:methanol: $20 \mathrm{mM} \mathrm{KHPO}_{4}, \mathrm{pH} 6.7$, $1 \mathrm{~mL} / \mathrm{min}$, u.v. $(220 \mathrm{~nm}) /$ radioactivity $(\mathrm{NaI})$, lower detection limits: $10-30 \mathrm{ng}$. Specific activities at the end of synthesis were in the range of $300-4000 \mathrm{Ci} /$ $\mathrm{mmol}$ and the radiochemical purities were greater than $98 \%$.

The following compounds were obtained from commercial sources: $\left[{ }^{3} \mathrm{H}\right]-N$-methyl scopolamine ([ $\left.\left.{ }^{3} \mathrm{H}\right] \mathrm{NMS}\right)(35-70 \mathrm{Ci} / \mathrm{mmol})$ (New England Nuclear), diethylstilbestrol (DES) (Aldrich Chemical Company), atropine sulfate (Sigma), scintillation cocktail (ICN Biomedical). Fischer F344 and Sprague-Dawley female rats were purchased (Harlan). Animals were exposed to alternating $12 \mathrm{~h}$ periods of light and dark and received rat chow and water ad libitum during the study.

\section{Tissue distribution studies}

Tissue distribution studies were performed in both F344 female rats weighing between 170 and $225 \mathrm{~g}$ at $5,15,45,60$ and $90 \mathrm{~min}$ post injection and in female Sprague-Dawley rats weighing between 150 and $250 \mathrm{~g}$. DES-treated rats were implanted as previously described (Otto et al., 1986) and used in tissue distribution studies at $0-16$ weeks post implant.
Radiolabeled drugs (50-200 $\mu \mathrm{Ci}$ in less than $250 \mu \mathrm{L}$ total volume) were administered intravenously (except where noted) in the femoral vein to rats anesthetized with ether. Animals ( $N=3$ per time interval) were anesthetized and killed by decapitation. The brains and other tissues were removed rapidly, counted for carbon-11 and then weighed. Tissue concentrations were calculated in terms of percent injected dose per gram $(\% \mathrm{ID} / \mathrm{g})$ or percent injected dose per organ (\%ID/organ). For QNB blocking studies, rats $(N=3)$ were pretreated intraperitoneally (i.p.) with \pm QNB (2 or $6.6 \mathrm{mg} / \mathrm{kg}$ body weight depending on study) either $10 \mathrm{~min}$ or $1 \mathrm{~h}$ prior to radiodrug injection. Control rats $(N=3)$ were pretreated with saline vehicle only.

\section{In vitro assay for heart tissue}

Hearts from DES-treated rats were excised at 10 and 16 weeks post DES implant and stored at $-80^{\circ} \mathrm{C}$ until used. Hearts from non-DES-treated rats were collected and frozen until used. For the assay, hearts were thawed and homogenized in ice-cold $50 \mathrm{mM}$ $\mathrm{Na}-\mathrm{K}$ phosphate buffer ( $\mathrm{pH}$ 7.4) (hereafter referred to as buffer); about $0.6 \mathrm{~g}$ tissue were homogenized in $11.5 \mathrm{~mL}$ buffer. Protein concentration was determined using the Bradford assay (Bradford, 1976) (standard: bovine serum albumin). Protein concentration of the homogenate was $0.24-0.28 \mathrm{mg} /$ assay volume. To assay the binding of $\left[{ }^{3} \mathrm{H}\right] \mathrm{NMS}$, triplicate samples of $50 \mu \mathrm{L}$ of homogenate in buffer containing a minimum of 10 different concentrations of $\left[{ }^{3} \mathrm{H}\right] \mathrm{NMS}$ were used. Nonspecific binding was also determined in triplicate by including $1 \mu \mathrm{M}$ atropine sulfate in the assay. Each assay was initiated by addition of homogenate to yield a final volume of $1.2 \mathrm{~mL}$ and incubated at room temperature for $2 \mathrm{~h}$. The assay was terminated by addition of $3.0 \mathrm{~mL}$ of ice-cold buffer followed by immediate vacuum filtration using glass fiber filters (Schleicher \& Schuell No. 32) presoaked in 2.5\% polyethylenimine. After washing the filters with $3 \times 3.0 \mathrm{~mL}$ cold buffer, they were transferred to a scintillation vial. Cocktail was added and the vials stored in the dark for $12 \mathrm{~h}$ before counting (64\% efficiency). The count data was analyzed using the LUNDON-1: Saturation Analysis: Radioligand Binding curve analysis package (Lundon Software Inc., Cleveland, Ohio).

\section{Results and Discussion}

Rat biodistribution studies were performed at $t=30 \mathrm{~min}$ (see Table 1). The expected differences in brain penetration of quaternized ([" $C] M T R B$ and $\left.\left[{ }^{11} \mathrm{C}\right] \mathrm{MQNB}\right)$ and neutral ([ $\left.\left.{ }^{1} \mathrm{C}\right] \mathrm{TRB}\right) \mathrm{mAChR}$ ligands was observed: the neutral ligand has a 300 -fold higher concentration in brain than the quaternized (positively charged) ligands. However, both neutral and quaternized radioligands had comparable pituitary uptake at $30 \mathrm{~min}$. Heart uptake was higher for $\left[{ }^{11} \mathrm{C}\right] \mathrm{MTRB}$ than for either $\left[{ }^{[1} \mathrm{C}\right] \mathrm{MQNB}$ or $\left[{ }^{11} \mathrm{C}\right] \mathrm{TRB}$ 
Table 1. Comparison of ["C]MTRB, ["C]MQNB and ["C]TRB in various rat* tissues at $t=30 \mathrm{~min}$; data as $\% \mathrm{ID} / \mathrm{g} \pm \mathrm{SEM}$

\begin{tabular}{lccc}
\hline Tissue & ["C]MTRB $\dagger$ & ["C]MQNB $\dagger$ & ["C]TRB $\ddagger$ \\
\hline Brain & $0.009 \pm 0.001$ & $0.010 \pm 0.000$ & $2.95 \pm 0.17$ \\
Pituitary & $1.03 \pm 0.12$ & $0.841 \pm 0.138$ & $1.58 \pm 0.19$ \\
Heart & $11.75 \pm 0.91$ & $7.71 \pm 1.54$ & $4.95 \pm 0.11$ \\
Blood & $0.032 \pm 0.005$ & $0.035 \pm 0.014$ & $0.111 \pm 0.027$ \\
\hline
\end{tabular}

- Fischer F344 female rats. $\uparrow N=3 . \ddagger N=10$.

(for further discussion of $\left[{ }^{11} \mathrm{C}\right] \mathrm{MTRB}$ in the myocardium see Mulholland et al., 1988c).

Blockade by QNB pretreatment of $\mathrm{mAChR}$, at $t=30 \mathrm{~min}$, was employed in order to demonstrate receptor mediation as the mechanism for tissue localization. Figure 2 shows the effects of QNB pretreatment $(2.0 \mathrm{mg} / \mathrm{kg}$ of \pm QNB $60 \mathrm{~min}$ prior to radiotracer administration) on the radioactivity localization in heart, pituitary and brain for $\left[{ }^{11} \mathrm{C}\right] \mathrm{TRB},\left[{ }^{11} \mathrm{C}\right] \mathrm{MTRB}$ and $\left[{ }^{1 !} \mathrm{C}\right] \mathrm{MQNB}$. QNB clearly reduced the tissue concentration of all compounds in the myocardium. Unexpectedly, the effects of QNB on pituitary uptake of neutral $\left(\left[{ }^{11} \mathrm{C}\right]\right.$ TRB $)$ and quaternized $\left(\left[{ }^{11} \mathrm{C}\right]\right.$ MTRB and $[" \mathrm{C}] \mathrm{MQNB}) \mathrm{mAChR}$ ligands were different. The uptake of $\left[{ }^{11} \mathrm{C}\right] \mathrm{TRB}$ was reduced by $17 \%$ when pretreated with QNB (control: $1.59 \pm 0.19 \% \mathrm{ID} / \mathrm{g}$; QNB: $1.31 \pm 0.09$ ) whereas the concentration of [ $\left.{ }^{11} \mathrm{C}\right] \mathrm{MTRB}$ in the pituitary was reduced by $68 \%$ and that of $\left[{ }^{11} \mathrm{C}\right] \mathrm{MQNB}$ by $85 \%$. Clearly the localization in normal pituitary of $\left[{ }^{11} \mathrm{C}\right] \mathrm{MTRB}$ and $\left[{ }^{11} \mathrm{C}\right] \mathrm{MQNB}$ can be significantly reduced by QNB pretreatment whereas only a small reduction is observed for ["C]TRB.

The pituitary uptake of $\left[{ }^{\prime \prime} \mathrm{C}\right] \mathrm{TRB}$ is similar to that reported for [ $\left.{ }^{3} \mathrm{H}\right] \mathrm{NMPB}$, a neutral $\mathrm{mAChR}$ antagonist (Avissar et al., 1981). Using a different protocol for QNB pretreatment, the uptake of $\left[{ }^{3} \mathrm{H}\right] \mathrm{NMPB}$ was reduced by about $30 \%$ in the pituitary. The QNB pretreatment protocol of Avissar et al. (1981) was followed except for the use of $6.6 \mathrm{mg} / \mathrm{kg}$ body weight of \pm QNB in place of $3.3 \mathrm{mg} / \mathrm{kg}$ of active QNB. This

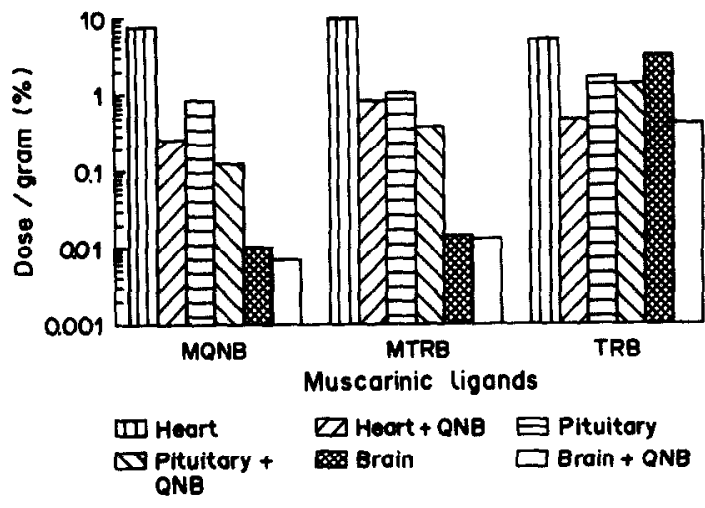

Fig. 2. Comparison of the effect of QNB on pituitary, heart and brain uptake at $t=30 \mathrm{~min}$. Fischer F344 rats were injected with vehicle only or with $2.0 \mathrm{mg} / \mathrm{kg}$ body weight $60 \mathrm{~min}$ prior to radioligand administration. Data are the average of $N=3$ for [ $\left.{ }^{11} \mathrm{C}\right] \mathrm{MQNB}$ and ["C]MTRB; $N=10$ for $\left[{ }^{11} \mathrm{C}\right] \mathrm{TRB}$.

protocol resulted in a reduction of ["C]TRB localization in brain and heart by $>79 \%$ but a reduction in the pituitary of less than $36 \%$. These results again demonstrate the inability of QNB to reduce pituitary

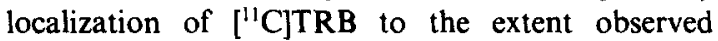
in other tissues containing $\mathrm{mAChR}$ receptors. We conclude that neutral $\mathrm{mAChR}$ antagonists behave differently in the pituitary than the quaternized antagonists. It is possible that the localization of $\left[{ }^{3} \mathrm{H}\right] \mathrm{NMPB}$ and $\left[{ }^{11} \mathrm{C}\right] \mathrm{TRB}$ in the pituitary is a combination of a non-mAChR specific uptake mechanism and a receptor-mediated mechanism with non$\mathrm{mAChR}$ uptake predominating. Differences in uptake between neutral and quaternized antagonists have been reported in the lung (Gibson et al., 1979). Similar results, i.e. largely non-receptor-mediated localization, were reported for the pituitary uptake of $\left[{ }^{3} \mathrm{H}\right]$ spiroperidol, a dopaminergic $\mathrm{D}_{2}$ antagonist (Otto et al., 1986b). Spiroperidol is similar to TRB and NMPB in that all are neutral amines. These results
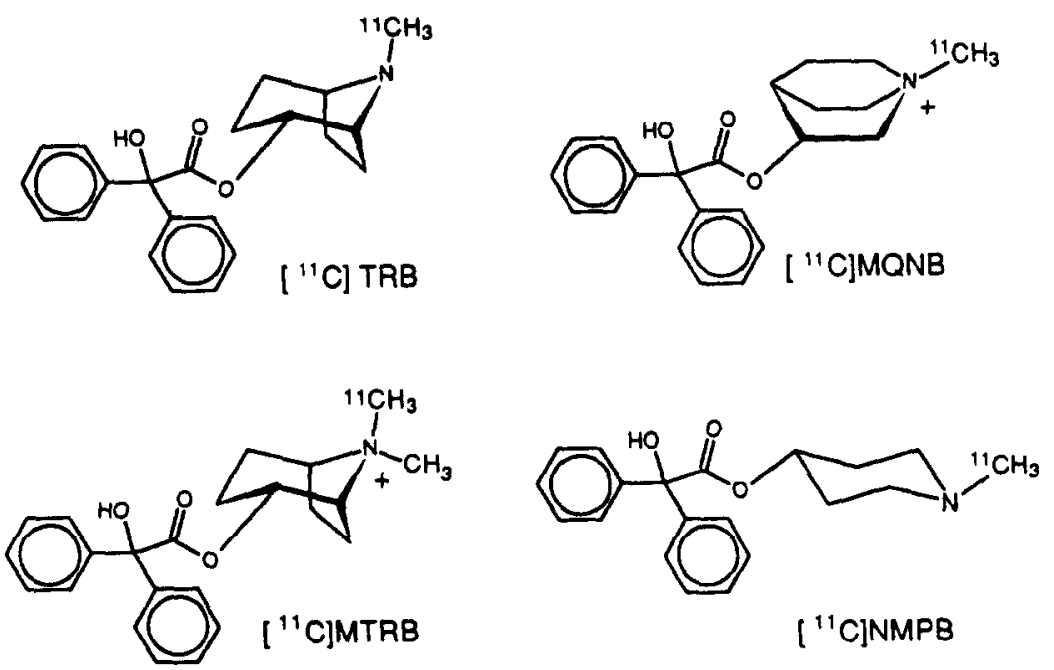

Fig. 1. Structures of $m A C h R$ antagonists. [" C]TRB and ["C]NMPB are neutral ligands; ["C]MTRB and ["C]MQNB are quaternized. 


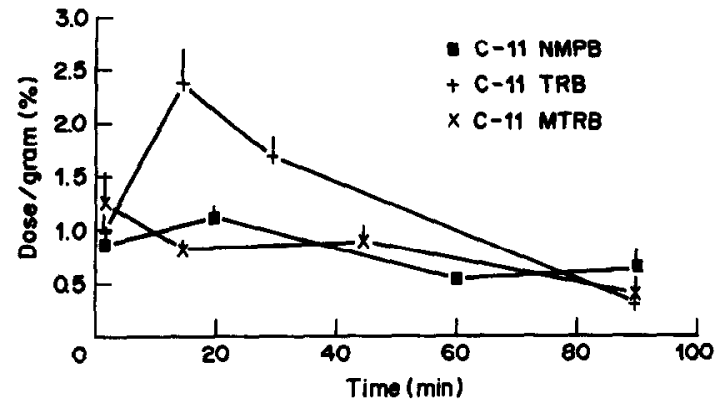

Fig. 3. Time course of radioactivity concentration of ["C]TRB, [" C]MTRB and [ "C]NMPB in pituitary tissue of Sprague-Dawley rats. Data as $\% \mathrm{ID} / \mathrm{g} \pm \mathrm{SEM} ; N=3$ for each data point.

suggest that a general mechanism for uptake of neutral amines operates in the pituitary.

We also compared the time course of $\left[{ }^{11} \mathrm{C}\right] \mathrm{MTRB}$, $\left[{ }^{11} \mathrm{C}\right] \mathrm{TRB}$ and $\left[{ }^{11} \mathrm{C}\right] \mathrm{NMPB}$ in the pituitary of SpragueDawley rats (sce Fig. 3). [ $\left.{ }^{\mathrm{l}} \mathrm{C}\right] \mathrm{TRB}$ has higher pituitary localization values than either [ $\left.{ }^{11} C\right] N M P B$ or ["C]MTRB. Despite the differences in effects of QNB pretreatment (about $30 \%$ for $\left[{ }^{3} \mathrm{H}\right] \mathrm{NMPB}$ and $68 \%$

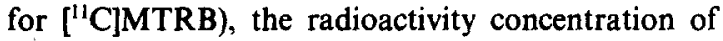
both ligands is similar at each time point.

To study the effect of DES exposure, the time course of $\left[{ }^{11}\right.$ C]MTRB in rats exposed to DES for 10 weeks, the effects of QNB pretreatment and the effects of differing lengths of exposure to DES on [ ${ }^{11}$ C]MTRB localization were determined. In contrast to the time course of $\left[{ }^{11} \mathrm{C}\right] \mathrm{MTRB}$ in Fischer F344 rats $(1.49 \pm$ $0.31 \% \mathrm{ID} / \mathrm{g}$ at $t=2 \mathrm{~min}$ to $1.71 \pm 0.42$ at $t=60 \mathrm{~min}$ ), the time course in DES-implanted animals showed a steadily decreasing \%ID/g tumor over the same time frame $(0.392 \pm 0.037$ to $0.134 \pm 0.002)$. Receptormediated localization was demonstrated as above. QNB pretreatment of rats exposed to DES for 6 weeks reduced [ $\left.{ }^{\prime} \mathrm{C}\right] \mathrm{MTRB}$ tumor localization by $77 \%$ (\% ID/g for controls was $0.442 \pm 0.107$; for $\mathrm{QNB}$ treated rats, $0.100 \pm 0.025$ ). As the length of exposure increases from 0 to 15 weeks, the \% ID/organ of $\left[{ }^{11} \mathrm{C}\right] \mathrm{MTRB}$ increases from $0.009 \pm 0.002$ for controls to $0.209 \pm 0.008$ at 15 weeks of DES, a 23 -fold increase. However, when corrected for increasing tumor weight the \%ID/g tumor decreased from 1.03 \pm 0.12 (control rats) to $1.28 \pm 0.22$ at 6 weeks DES to $0.830 \pm 0.00 \mathrm{~g}$ at 15 weeks DES.

Histological characterization of the DES-induced tumors after 4 weeks of DES exposure in female F344 rats showed (1) that the percent of prolactin (PRL) secreting cells increased from $32.3 \pm 1.4 \%$ to 79.7 \pm 1.0 , a 2.5 -fold increase, and (2) that there was a 5-fold increase in serum PRL levels (Otto et al., 1986a). Since the \%ID/g tumor decreases while the percent of PRL secreting cells increases, it appears that there may be changes in either $B_{\max }$ or $K_{\mathrm{D}}$ relative to normals. It is not clear whether these results are due to DES or to high circulating levels of prolactin. The presence of estrogen affected in vitro agonist binding to $\mathrm{mAChR}$ by reducing the proportion of high affinity binding sites and by decreasing the dissociation constant (Sokolovsky et al., 1981). If estrogen effects occur in vivo, the changes in localization of $\left[{ }^{11} \mathrm{C}\right]$ MTRB, albeit an antagonist instead of an agonist, may be related to DES presence. Efforts are underway to determine these binding characteristics in DES-treated pituitary tissue.

The heart uptake of $\left[{ }^{\prime \prime} C\right] M T R B$ appears to be constant from 6 to 15 weeks of exposure to DES, suggesting that minimal change in myocardial $\mathrm{mAChR}$ density or in kinetic behavior results from high circulating PRL levels (Otto et al., 1986a). Competitive binding assays using hearts from the DES treated rats at 10 and 16 weeks post implant were compared to data from normal hearts. [ $\left.{ }^{3} \mathrm{H}\right] \mathrm{NMS}$ (Brown and Goldstein, 1986; Aguilar and De Robertis, 1987) was employed as radioligand in this assay as it is a quaternized ligand and thus similar to [ $\left.{ }^{11} \mathrm{C}\right]-$ MTRB. In each case, analysis of binding data using LUNDON-1 was performed. Comparison of a model for one site with a model for one site plus nonsaturable binding (the next most complex binding model), yielded $F$ test scores of $<0.01$ and runs test scores of $>0.05$. Both scores support the one site model as the best fit for the data (Lundeen and Gordon, 1986). A minimum of 14 different ligand concentrations were included in each curve analysis. Non-linear analyses werc used as opposed to Scatchard-Rosenthal analysis to determine $K_{\mathrm{D}}$ and $B_{\max }$ values. Values of $K_{\mathrm{D}}$ did not change: for normal hearts, $K_{\mathrm{D}}$ was $5.8 \pm 0.3 \times 10^{-11} \mathrm{~mol}$; for 10 week DES hearts, $4.8 \pm 0.4 \times 10^{-11}$; for 16 week DES, $5.0 \pm 0.25 \times 10^{-11}$. Values for $B_{\max }$ were similar for control hearts $\left(8.6 \pm 0.4 \times 10^{-14} \mathrm{~mol} / \mathrm{mg}\right.$ protein $)$ and 10 week DES hearts $\left(7.9 \pm 0.2 \times 10^{-14}\right)$. These data are in agreement with a study which showed that the density of mAChR, as measured with [ $\left.{ }^{3} \mathrm{H}\right] \mathrm{QNB}$, was constant in rats implanted with the MtTW15 adenoma for 5 weeks (Nelson et al., 1987). $B_{\max }$ values in 16 week DES hearts increased to $16 \pm 2 \times 10^{-14}$. Further study is needed to verify and determine the significance of this increase.

In conclusion, these studies have shown that $\left[{ }^{11} \mathrm{C}\right] \mathrm{TRB}$ localization in the pituitary is not primarily receptor-mediated whereas the localization of the quaternized ligands, $\left[{ }^{11} \mathrm{C}\right] \mathrm{MTRB}$ and $\left[{ }^{11} \mathrm{C}\right] \mathrm{MQNB}$ is receptor-mediated as demonstrated by reduction of radioactivity levels in the presence of QNB. The presence of DES-induced prolactinomas decreased tissue concentration of [ $\left.{ }^{\prime \prime} C\right] M T R B$ in the pituitary. DES treatment did not affect ["C]MTRB localization in the myocardium as evidenced by tissue concentration values and by similarity in $K_{\mathrm{D}}$ and $B_{\max }$ value in normal and 10 week DES-treated rat hearts.

Acknowledgements-We are grateful to $\mathrm{Dr}$ Edward $\mathrm{R}$. Atkinson for his interest and contributions to the TRB related studies. Research was supported by Grants DE FG02 87ER60528 and DE FG02 87ER60561 from the Department of Energy and Grant 2-P01-NS15655-08 from NINCDS. 


\section{References}

Aguilar J. S. and De Robertis E. (1987) The properties of cholinergic muscarinic receptor sites from bovine atria reconstituted after solubilization. Neurochem. Int. 11, 273.

Atkinson E. R., McRitchie D. D. Shoer L. F., Harris L. S. Archer S., Aceto M. P., Pearl J. and Luduena F. P. (1977) Parasympatholytic (anticholinergic) esters of the isomeric 2-tropanols. 1. Glycolates. J. Med. Chem. 20, 1612.

Avissar S., Egozi Y. and Sokolovsky M. (1981) Biochemical characterization and sex dimorphism of muscarinic receptors in rat adenohypophysis. Neuroendocrinology 32, 303.

Biel J. H., Abood L. G., Hoya W. K., Leiser H. A., Nuhfer P. A. and Kluchesk E. F. (1961) Central stimulants. II. Cholinergic blocking agents. J. Org. Chem. 26, 4096.

Bradford M. M. (1976) A rapid and sensitive method for the quantitation of microgram quantitics of protein utilizing the principle of protein-dye binding. Analyt. Biochem. 72, 248.

Brown J. H. and Goldstein D. (1986) Analysis of cardiac muscarinic receptors recognized selectively by nonquaternary but not by quaternary ligands. J. Pharmac, Exp. Ther. 238, 580.

Burt D. L. and Taylor R. L. (1980) Muscarinic receptor binding in sheep anterior pituitary. Neuroendocrinology 30, 344 .

Carmeliet P. and Denef C. (1988) Immunocytochemical and pharmacological evidence for an intrinsic cholinomimetic system modulating prolactin and growth hormone release in rat pituitary. Endocrinology 123, 1128 and refs therein.

Gibson R. E., Eckelman W. C., Vieras F. and Reba R. C. (1979) The distribution of the muscarinic acetylcholine receptor antagonists quinuclidinyl benzilate and quinuclidinyl benzilate methiodide (both tritiated), in rat, guinea pig, and rabbit. J. Nucl. Med. 20,865 .

Hall T. R., Harvey S. and Chadwick A. (1984) Serotonin and acetylcholine affect the release of prolactin and growth hormone from pituitary glands of domestic fowl in vitro in the presence of hypothalamic tissue. Acta Endocrinol. (Copenhagen) 105, 455.

Lundeen J. E. and Gordon J. H. (1986) Computer analysis of binding data. In Receptor Binding in Drug Research, pp. 31-49. Dekker, New York.

Maziere M., Comar D., Godot J. M., Collard P., Cepeda C. and Naquet R. (1981) In vivo characterization of myocardium muscarinic receptors by positron emission tomography. Life Sci. 29, 2391.

Mukherjee A., Snyder G. and McCann S. M. (1980) Characterization of muscarinic cholinergic receptors on intact rat anterior pituitary cells. Life Sci. 27, 475 .

Mulholland G. K., Jewett D. M., Otto C. A., Kilbourn M. R., Sherman P. S. and Kuhl D. E. (1988a) Synthesis and regional brain distribution of $[\mathrm{C}-11] N$-methy $]-4-$ piperidyl benzilate ([C-11]NMPB) in the rat. J. Nucl. Med. 29, P768.
Mulholland G. K., Jewett D. M., Otto C. A., Kilbourn M. R., Sherman P. S., Koeppe R. A., Wieland D. M., Frey K. A. and Kuhl D. E. (1988b) Synthesis and preliminary evaluation of $[\mathrm{C}-11]-(+)-2$-tropanyl benzilate (C-11TRB) as a ligand for the muscarinic receptor. $J$. Nucl. Med. 29, $\mathrm{P932}$.

Mulholland G. K., Schwaiger M., Otto C. A., Sherman P. S, and Jewett D. M. (1988c) New positron labeled quaternized muscarinic ligand as potential PET imaging agent. Circulation 78, 598.

Mulholland G. K., Schwaiger M., Otto C. A., Sherman P. S. and Jewett D. M. (1989) Synthesis and animal studies of C-11 tropanyl benzilate methiodide (MTRB). A promising ligand of peripheral muscarinic receptors. J. Nucl. Med. 30, P930.

Neison C. A., Katovich M. J. and Baker S. P. (1987) Beta-adrenergic responsiveness and cardiac autonomic receptors after implantation of the MtTW15 pituitary adenoma in the rat. Biochem. Pharmacol. 36, 1297.

Otto C. A., Marshall J. C., Lloyd R. V., Sherman P. S., Fisher S. J., Valoppi V. L., Rogers W. L. and Wieland D. M. (1986a) Use of DES-treated rats as an animal model for assessment of pituitary adenoma imaging agents. Nucl. Med. Biol. 13, 539.

Otto C. A., Sherman P. S., Fisher S. J., Valoppi V. L., Marshall J. C., Lloyd R. V., Rogers W. L. and Wieland D. M. (1986b) Pituitary localization of ${ }^{3} \mathrm{H}$-spiroperidol by an uptake/storage mechanism? Nucl. Med. Biol. 13, 533.

Otto C. A., Mulholland G. K., Perry S. E., Combs R., Sherman P. S. and Fisher S. J. (1989) In vitro and ex vivo evaluation of cyclic aminoalkyl benzilates as potential emission tomography ligands for the muscarinic receptor. Nucl. Med. Biol. 16, 51 .

Schaeffer J. M. and Hsueh A. J. W. (1980) Acetylcholine receptors in the rat anterior pituitary gland. Endocrinology $106,1377$.

Sharif N. A. (1988) Chronic prolactin, gonadal and thyroid hormone treatments in vivo alter levels of TRH and muscarinic receptors in male and female rat tissues. Brain Res. 449, 364.

Sokolovsky M., Egozi. Y. and Avissar S. (1981) Molecular regulation of receptors; interaction of $\beta$-estradiol and progesterone with the muscarinic system. Proc. Natl. Acad. Sci. U.S.A. 78, 5554.

Sokolovsky A., Egozi Y. and Kloog Y. (1980) Biochemical characterization of muscarinic receptors. Monogr. Neural Sci. 7, 30 .

Syrota A., Comar D., Paillotin G., Davy J.-M., Aumont M.-C., Stulzaft O. and Maziere B. (1985) Muscarinic cholinergic receptor in the human heart evidenced under physiological conditions by positron emission tomography. Proc. Natl. Acad. Sci. U.S.A. 82, 584.

Wiklund J., Wertz N. and Gorski J. (1981) A comparison of estrogen effects on uterine and pituitary growth and prolactin synthesis in F344 and Holtzmann rats. Endocrinology 109, 1700. 